\title{
MELACAK AKAR BIAS GENDER DALAM STUDI ISLAM
}

\author{
Maulana \\ Fakultas Ushuludin dan Pemikiran Islam \\ UIN Syarif Hidayatullah Jakarta \\ Email: maulana@uinjkt.ac.id
}

\begin{abstract}
Abstrak: This paper will try to decipher some of the contemporary issues related to the root of the problem of gender bias in the study of Islam. Among the issues which form the basis of the emergence of gender bias in the study of Islam is the First, the issue of the creation of Eve in Sura al-Nisa verse 1. Second, the issue of leadership of women over men. Third, Woman and Sin Heritage. From this context, it can be understood that the teachings of Islam do not subscribe to the ideology that prohibits female lead, also bebrabai myth tentan creation of Eve. Because, it all would give a heavy burden on women. Like the myth of menstruating women as though he had not seen and treated as human beings, because in addition to be consigned should also perform various hard rituals.
\end{abstract}

Keywords: Bias gender, studi Islam, perempuan

\section{PENDAHULUAN}

Menjelang akhir abad kedua puluh, telah muncul kesadaran yang cukup membanggakan bahwa selama ini telah banyak terjadi dan berlangsung diskriminasi dan ketidakadilan gender (gender inequalities) yang menimpa kaum perempuan. Beberapa fenomena yang meujuk pada rasa ketidakadilan gender itu paling tidak mencakup pada isu;

Pertama, marginalisasi perempuan baik di rumah tangga, di tempat kerja, maupun di dalam bidang kehidupan bermasyarakat lainnya. Proses marginalisasi ini berakibat pada pemiskinan ekonomi perempuan;

$$
\text { Kedua, subordinasi terhadap }
$$

perempuan karena adanya anggapan bahwa perempuan itu irrasional, emosional, maka ia tidak bisa memimpin dan oleh karena itu harus ditempatkan pada posisi yang tidak penting;

Ketiga, stereotype yang merugikan kaum perempuan, misalnya asumsi bahwa mereka suka dandan dan itu untuk menarik perhatian lawan jenis sehingga menimbulkan kekerasan seksual;

Keempat, berbagai bentuk kekerasan menimpa perempuan baik fisik maupun psikologis karena adanya anggapan bahwa perempuan itu lemah; dan

Kelima, pembagian kerja secara seksual yang merugikan kaum perempuan, misalnya perempuan hanya cocok dengan pekerjaan domestik, oleh sebab itu tidak pantas melakukan pekerjaan publik seperti laki-laki. Akibatnya perempuan terkurung dalam ruang dan wawasan yang sempit. ${ }^{1}$

Persoalan ini, memicu munculnya beberapa pemikir Islam untuk mengkaji 
ketidakadilan gender ini, dalam berbagai aspek, diantaranya adalah pendidikan Islam. Diaspek yang lain, tepatnya pada aspek teologis, ada Riffat Hasan dari Pakistan. ${ }^{2}$ Aspek politik ada Fatima Mernissi. ${ }^{3}$ Dari aspek sejarah ada Leila Ahmed. dan sebagainya. ${ }^{4}$

Perempuan, baik sebagai individu beragama maupun sebagai individu dalam konteks bernegara, statusnya adalah sama dengan berbagai hak dan kewajiban dimilikinya sebagaimana kaum laki-laki. Dengan demikian, agama dan negara semestinya wajib melindungi seluruh umat beragama dan waga negaranya dari berbagai bentuk pelanggaran terhadap hak asasinya baik secara struktural maupun kultural, tanpa membeda-bedakan jenis kelamin, ras, bahasa, golongan, warna kulit maupun agama. Oleh karen itu, tulisan ini akan mencoba menguraikan beberapa isu kontemporer terkait akar probelmatika bias gender dalam studi Islam.

\section{Recovering Makna Gender}

Kata gender berasal dari bahasa Inggris berarti "jenis kelamin",5 yaitu perbedaan yang tampak antara laki-laki dan perempuan dilihat dari segi nilai dan tingkah laku. ${ }^{6}$ Pengertian lain dijelaskan bahwa gender adalah suatu konsep kultural yang berupaya membuat pembedaan (distinction) dalam hal peran, perilaku, mentalitas, dan karakteristik emosional antara laki-laki dan perempuan yang berkembang dalam masyarakat. ${ }^{7}$

Menurut Hilary M. Lips, gender merupakan harapan-harapan budaya terhadap laki-laki dan perempuan (cultural expectations for women and men). ${ }^{8}$ Pendapat ini sejalan dengan pendapat kaum feminis, seperti Lindsey yang menganggap semua ketetapan masyarakat perihal penentuan seseorang sebagai laki-laki atau perempuan adalah termasuk bidang kajian gender (What a given society defines as masculine or feminin is a component of gender). ${ }^{9}$

Sementara H. T. Wilson mengartikan gender sebagai suatu dasar untuk menentukan pengaruh faktor budaya dan kehidupan kolektif dalam membedakan lakilaki dan perempuan. ${ }^{10}$ Pandangan ini, agak sejalan dengan pendapat Showalter yang mengartikan gender lebih dari sekedar pembedaan laki-laki dan perempuan dilihat dari konstruksi sosial budaya, tetapi menekankan gender sebagai konsep analisa dalam mana kita dapat menggunakannya untuk menjelaskan sesuatu (Gender is an analityc concept whose meanings we work to elucidate, and a subject matter we proceed to study as we try to define it). ${ }^{11}$

Kata gender belum masuk dalam perbendaharaan Kamus Besar Bahasa Indonesia, tetapi istilah tersebut sudah lazim digunakan, khususnya di Kantor Menteri Negara Urusan Peranan Wanita dengan istilah "jender". Jender diartikan sebagai 
"interpretasi mental dan kultural terhadap perbedaan kelamin yakni laki-laki dan perempuan. Jender biasanya dipergunakan untuk menunjukkan pembagian kerja yang dianggap tepat bagi laki-laki dan perempuan". 12

Dari berbagai definisi di atas dapat disimpulkan bahwa gender adalah suatu konsep yang digunakan untuk mengidentifikasi perbedaan laki-laki dan perempuan dilihat dari segi pengaruh sosial budaya. Gender dalam arti ini adalah suatu bentuk rekayasa masyarakat (social constructions), bukannya sesuatu yang bersifat kodrati.

Dengan demikian, persoalan gender tidak semata-mata mempersoalkan perbedaan dan pembedaan un sich antara laki-laki dan perempuan; terlebih penting lagi ia menyangkut dominasi baik dari konteks relasi maupun distribusi kekuasaan. ${ }^{13}$ Kondisi inilah -disadari atau tidak-yang seringkali melahirkan dan melembagakan berbagai ketidakadilan gender.

Menurut Faqih,14 gender dipengaruhi dan dibingkai oleh banyak hal, dan komponen determinatifnya sangat variatif, seperti nilai-nilai budaya, tradisi agama, sosial dan sistem politik. Gender dikonstruksi baik sengaja maupun tidak, dan disosialisasikan pertama kali melalui institusi keluarga, lingkungan sosial dan sekolah, dan kemudian dicarikan dasar penopang ideologisnya untuk menguatkan jenis perbedaan tersebut. Dalam kaitan di atas, teks dan doktrin keagamaan sering dijadikan sebagai tempat berlindung dan acuan utama untuk merumuskan pemikiran diskursif tentang gender

Secara konseptual, problem gender diawali oleh adaya peran-peran yang berbeda (yang seringkali diskriminatif) pada laki-laki dan perempuan terhadap sesuatu yang didasarkan atas pembagian kerja menurut kategori jenis kelamin dan asumsi ideologi patriarki. Akibat kuatnya ideologi gender yang patriarkis yang berkembang di masyarakat ini, maka laki-laki dan perempuan tidak mempunyai kebebasan untuk menentukan pilihan peran-peran sosial dan kultural karena secara faktual ketidakadikan gender telah termanifestasikan dalam pelbagai bentuk keyataan sosial, budaya, ekonomi, politik dan agama.

Sementara, dalam konteks agama Islam, problem gender ini salah satunya dilatarbelakangi oleh "kekurangarifan" dalam menafsirkan dalil-dalil agama Islam yang kemudian seringkali dijadikan dasar utuk menolak kesetaraan jender. Kitab-kitab tafsir dijadikan referensi untuk melegitimasi paradigma patriarki, yang memberikan hakhak istimewa kepada laki-laki dan cenderung memojokkan perempuan dengan pendefinisian yang negatif. Pendefinisian sosok perempuan yang negatif ini kemudian diwariskan secara turun temurun yang pada 
akhirnya mengendap dalam alam bawah sadar perempuan yang menimbulkan ketimpangan relasi antara laki-laki dan perempuan dalam hubungannya sebagai hamba tuhan. Dengan kata lain pemahaman akan posisi perempuan yang bias gender sudah dengan sendirinya tertradisikan di masyarakat yang dibakukan oleh konstruksi budaya dan doktrin keagamaan serta ditopang oleh nilai-nilai kultural dan ideologis.

Menurut Mohammad Yasir Alimi, ketidakadilan dan diskriminasi perempuan disebabkan oleh dua faktor, yaitu faktor budaya dan hukum. Dalam masyarakat terdapat budaya yang cenderung male chauvinistic, dimana kaum laki-laki menganggap diri dan dianggap sebagai makhluk yang kuat dan superior. Budaya male chauvinistic itu diperkokoh dengan ideologi misoginis (sikap benci kepada perempuan) dan ideologi patriarki. Dalam isi hukum, budaya hukum, serta proses dan pembuatan dan penegakkan hukum yang dibuat negara, seringkali diskriminatif terhadap perempuan, karena pembuat hukum tidak respon terhadap kebutuhan masing-masing jenis kelamin (gender blind) dan tidak memahami kebutuhan spesifik perempuan. ${ }^{15}$

Sementara itu menurut Masdar. F. Mas'udi ketidakadilan dan diskriminasi terhadap perempuan dalam masyarakat disebabkan oleh banyak faktor. Pada awalnya adalah disebabkan adanya stereotype yang cenderung merendahkan posisi kaum perempuan, seperti bahwa perempuan itu lemah, lebih emosional daripada nalar, cengeng tidak tahan banting, tidak patut hidup selain di dalam rumah, dan sebagainya.16 Mmenurutnya ada empat persoalan yang menimbulkan stereotype terhadap perempuan;

Pertama, melalui subordinasi, kaum perempuan harus tunduk kepada kaum lakilaki. Pemimpin (imam) hanya pantas dipegang oleh laki-laki, sedangkan perempuan hanya boleh menjadi yang dipimpin (ma'mum). Perempuan boleh menjadi pemimpin hanya terbatas pada kaumnya saja, yang berfungsi sebagai pendukung kegiatan utama kaum laki-laki, misalnya di Dharma Wanita, Muslimat, Aisyiah, Fatayat dan sebagainya.

Kedua, Perempuan cenderung dimarginalkan, yaitu diposisikan dipinggir. Dalam kegiatan masyarakat, perempuan paling tinggi hanya menjadi seksi konsumsi atau penerima tamu saja. Dalam rumah tangga, perempuan adalah konco wingking di dapur.

Ketiga, Kaum perempuan berada dalam posisi yang lemah, karenanya kaum perempuan sering menjadi sasaran tindak kekerasan (violence) oleh kaum laki-laki. Dalam masyarakat, bentuk kekerasan itu mulai dari digoda, dilecehkan, dipukul, dicerai sampai diperkosa. 
Keempat, akibat ketidakadilan gender itu, kaum perempuan harus menerima beban pekerjaan yang lebih berat dan lebih lama daripada yang dipikul kaum laki-laki. Dalam bekerja, laki-laki paling aktif maksimal bekerja rata-rata 10 jam/hari, sedangkan perempuan bekerja 18 jam/hari. Pada umumnya beban ini dianggap remeh oleh kaum laki-laki, karena secara ekonomi dinilai kurang berarti. ${ }^{17}$

\section{Akar Persoalan Gender dalam Islam}

Di antara persoalan yang menjadi dasar terhadap munculnya bias gender dalam studi Islam adalah Pertama, persoalan penciptaan hawa pada Surah al-Nisa ayat 1 . Dalam al-Qur'an tidak dijumpai ayat-ayat secara rinci menceritakan asal-usul kejadian perempuan. Kata Hawa yang selama ini dipersepsikan sebagai perempuan yang menjadi isteri Adam sama sekali tidak pernah ditemukan dalam al-Qur'an, bahkan keberadaan Adam sebagai manusia pertama dan berjenis kelamin laki-laki masih dipermasalahkan. ${ }^{18}$ Satu-satunya ayat yang mengisyaratkan asal usul kejadian perempuan yaitu QS. al-Nisa'/4 ayat 1 sebagai berikut:

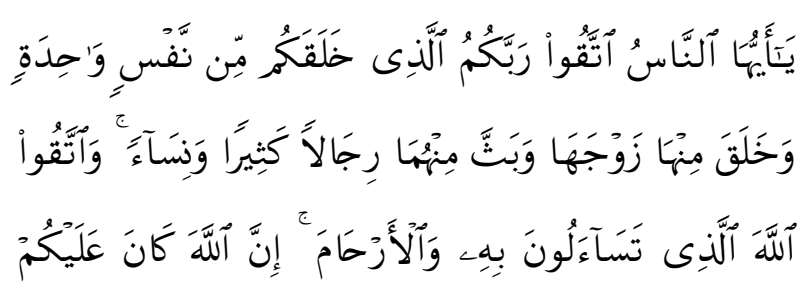

Hai sekalian manusia, bertakwalah kepada Tuhanmu yang telah menciptakan kamu dari "diri" yang satu (a single self), dan dari padanya Allah menciptakan pasangan (pair)-nya, dan dari pada keduanya Allah memperkembangbiakkan laki-laki dan perempuan yang banyak. Dan bertakwalah kepada Allah yang dengan (mempergunakan) nama-Nya kamu saling meminta satu sama lain, dan (peliharalah) hubungan silaturrahim. Sesungguhnya Allah selalu menjaga dan mengawasimu.

Akan tetapi maksud ayat ini masih terbuka peluang untuk didiskusikan, karena ayat tersebut menggunakan kata-kata bersayap. Para mufassir juga masih berbeda pendapat, siapa sebenarnya yang dimaksud dengan "diri yang satu" (nafs al-wahidah), siapa yang ditunjuk pada kata ganti (dhamir) "dari padanya" (minha), dan apa yang dimaksud "pasangan" (zawy) pada ayat tersebut?

Berikut adalah bberapa pendapat ulama erkait dengan tafsir atas ayat tersebut. Imam Athûsiy (385-460 H.) menjelaskan sebagai berikut:

"Yang dimaksud dengan ungkapan "min nafsin wâhidatin" pada ayat ini adalah Àdam menurut mufasir: asSuddiy, Qatâdah, Mujâhid dan yang lainnya. Sedangkan yang dimaksud dengan ungkapan "wa khalaqa minhâ zawjahâ" yakni Hawwâ. Diriwayatkan bahwa Hawwâ diciptakan dari salah satu tulang rusuk Àdam. Mayoritas mufasir mengikuti pendapat ini". 19

Sementara menurut AzZamakhsyariy (467-538 H.) ayat tersebut 
menunjukkan bahwa Allah menciptakan manusia berasal dari seorang pribadi, yaitu Àdam Ab al-Basyar yang diistilahkan dengan nafsin wâkhidatin. Sementara wa khalaqa minhâ zawjahâ dapat dihubungkan (di'athafkan) kepada dua kemungkinan sebagai, yaitu ; Pertama, ayat itu dihubungkan kepada kalimat yang dihilangkan. Jadi seakan-akan Allah berfirman: "Hai manusia,bertakwalah kalian kepada Tuhan kalian yang telah menjadikan kalian dari seorang pribadi yang Dia ciptakan sendiri dan daripadanya pula Dia ciptakan isterinya". Di sini kalimat yang dihilangkan adalah "ansya'ahâ aw ibtada'ahâ", karena makna kalimat itu sudah tersirat dalam pengertian ayat. ${ }^{20}$

Selanjutnya az-Zamakhsyariy menjelaskan:

Allah menciptakan kalian dari seorang pribadi yang Dia ciptakan sendiri dari tanah/debu (turâb) dan Dia menciptakan isterinya Hawwâ dari salah satu tulang rusuknya. Kemudian diperkembangbiakkan-Nya dari mereka berdua, laki-laki dan perempuan yang banyak. Dalam menyebut laki-laki dan perempuan pada ayat tersebut, yang diberikan sifat hanyalah laki-laki (rijâlan katsîran), sedangkan perempuan tidak diberi kata sifat lagi. Hal ini menunjukkan bahwa penciptaan mereka semua berasal dari jenis laki-laki. ${ }^{21}$
Kedua, ungkapan “wa khalaqa minhâ zawjahâ" dapat pula dihubungkan kepada ungkapan "khalaqakum".22 Abu Hayyân alAndalusiy (654-745 H.) menjelaskan: Yang dimaksud dengan ungkapan "nafsin wâkhidatin" adalah Àdam, ${ }^{23}$ sementara penciptaan Hawwâ berasal dari diri Àdam. Untuk itu ia mengutip riwayat yang dikemukkan oleh Ibnu 'Abbâs, Mujâhid, asSuddiy, dan Qatâdah yang mengatakan: "Allah menciptakan Àdam kesepian di surga sendirian, kemudian ia tidur, lalu Allah mencabut salah satu tulang rusuknya sebelah kiri (ada pendapat yang mengatakan tulang rusuknya sebelah kanan) yang lebih pendek, lalu Dia ciptakan Hawwâ" ${ }^{24}$

Sementara Ibnu Katsîr (705-774 H) menjelaskan bahwa yang dimaksud dengan ungkapan "min nafsin wâkhidatin" adalah Àdam, sedangkan ungkapan “wa khalaqa minhâ zawjahâ" adalah Hawwâ yang diciptakan dari tulang rusuk Àdam yang sebelah kiri, setelah diciptakan Àdam, ketika ia sedang tertidur. Begitu ia terbangun, ia melihatnya dan mengaguminya lalu tertarik kepadanya. Hawwâ pun tertarik pula kepada Àdam. ${ }^{25}$ Imâm as-Suyuthiy (849-911 H.) dan al-Makhalliy (791-864 H.) menjelaskan bahwa yang dimaksud dengan ungkapan "min nafsin wâkhidatin" adalah Àdam, sedangkan ungkapan "wa khalaqa minhâ zawjahâ" adalah Hawwâ. ${ }^{26}$

Abu as-Su'd (893-982 H.) menjelaskan bahwa Allah telah menciptkan Àdam as. 
kemudian menciptakan Hawwâ dari tulang rusuk Àdam as. Diriwayatkan bahwa Allah 'Azza wa Jalla ketika menciptakan Àdam as. Dia tempatkan di dalam surga, lalu Dia jadikan Àdam as. itu tertidur. Dalam kondisi Àdam as. antara tidur dan jaga, Allah ciptakan Hawwâ dari salah satu tulang rusuk Àdam as. yang sebelah kiri. Ketika Àdam as. betul-betul jaga, dia temukan Hawwâ sudah berada di sisinya. ${ }^{27}$

Adapun Kitab-kitab Tafsir Moderen yang penafsirannya masih senada dengan penafsiran kitab-kitab tafsir klasik, yakni masih bias gender diantaranya adalah AlQâsimiy (1866-1914 M.) menafsirkan ayat tersebut sebagai berikut: Hai sekalian manusia, bertakwalah kalian kepada Tuhan kalian yang telah menciptakan kalian dari seorang pribadi, yaitu Àdam. Kemudian Dia ciptakan pula baginya seorang isteri, yaitu Hawwâ yang berasal dari diri Àdam itu sendiri.

\section{Selanjutnya}

Allah memperkembangbiakkan dari keduanya lakilaki dan perempuan yang banyak dengan jalan beranak dan berketurunan. Kata sifat dari nisấan tidak disebutkan dengan jelas, karena dari kata sifat untuk laki-laki, yaitu "katsîran" sudah tercakup pula perempuan. ${ }^{28}$

Kemudian Akhmad Musthafâ alMarâgiy (1883-1952 H.) mengatakan bahwa yang dimaksud dengan ungkapan "min nafsin wâkhidatin" adalah Àdam....sedangkan ungkapan "wa khalaqa minhâ zawjahâ" adalah
Hawwâ yang diciptakan dari tulang rusuknya yang sebelah kiri ketika ia sedang tidur. $^{29}$

Mukhammad 'Aliy as-Syâbniy, Guru Besar Fakultas Syarî́ah dan Studi Islam di Mekah al-Mukarramah mengatakan:

Yang dimaksud dengan ungkapan "min nafsin wâkhidatin" adalah "ansya'akum min a،lin wâkhidatin wa huwa abîkum Àdam" yakni Allah menciptakan kalian dari satu asal, yaitu moyang kalian Àdam, sedangkan ungkapan "wa khalaqa minhâ zawjahâ wa hiya Hawwâ" yakni Allah ciptakan dari diri Àdam tadi isterinya, yaitu Hawwâ. ${ }^{30}$

Abu Bakr Jâbir al-Jazâ'iriy, penasihat Mesjid Nabawiy di Madînah mengatakan bahwa yang dimaksud dengan ungkapan "min nafsin wâhidatin" adalah Àdam as., sedangkan yang dimaksud dengan ungkapan “wa khalaqa minhâ zawjahâ" adalah "khalaqa Hawwâ min Àdam, min «il'ihi” yakni Allah menciptakan Hawwâ itu dari diri Àdam, yaitu dari tulang rusuknya. ${ }^{31}$

Wahbah az-Zuhayliy, Ketua Jurusan Fiqh Islam dan Mazhab-mazhabnya di Universitas Damaskus mengatakan:

Yang dimaksud dengan ungkapan "minnafsin wâkhidatin" menurut mayoritas ulama tafsir adalah Àdam as. yang merupakan moyangnya manusia, tidak ada lagi Àdam yang lain, kecuali dia sendiri. Pendapat yang menyatakan adanya Àdam-Àdam yang lain, 
bertentangan dengan ungkapan tegas Alquran.32 Adapun yang dimaksud dengan ungkapan "wa khalaqa minhâ zawjahâ" adalah "Hawwâ yang Allah ciptakan dari tulang rusuk Àdam yang sebelah kiri, ketika ia sedang tidur, kemudian ia terjaga dan kagum melihatnya dan tertarik kepadanya, Hawwâ pun juga demikian".33

Semua tafsir tersebut, baik tafsir klasik maupun tafsir moderen yang menggunakan interpretasi tekstual, terutama yang menjadikan hadis Nabi Saw. sebagai penjelas atau penafsir ayat tersebut. Mereka seolah sepakat mengatakan bahwa yang dimaksud dengan ungkapan "min nafsin wâkhidatin" adalah Àdam as. sebagai moyangnya manusia, sedangkan ungkapan “wa khalaqa minhâ zawjahâ" adalah Allah swt. menciptakan Hawwâ dari diri Àdam, tegasnya dari tulang rusuknya. Ada yang menyatakan tulang rusuknya yang sebelah kiri dan ada pula yang menyatakan tulang rusuknya yang kanan.

Dari uraian diatas, menunjukkan bahwa para mufassir tersebut memaknai min nafsi wahidah dan wa khalaqa minha zawjaha sebagai Hawa tercipta dari tulang rusuk Adam. Akan tetapi ada juga beberapa mufasir yang mengartikan ayat tersebut, dengan agak berbeda. Misalnya Muhammad Abduh (1849-1905 M.) mengatakan, bahwa makna yang dimaksudkan dari ungkapan “wa khalaqa minhâ zawjahâ" menurut mayoritas ulama tafsir adalah bahwa Allah menciptakan untuk "an-Nafs" yakni Àdam, isterinya Hawwâ dari "an-Nafs" itu sendiri.

Mereka mengatakan bahwa Hawwâ diciptakan dari tulang rusuknya yang sebelah kiri. Hal ini disebutkan secara tegas dalam Kitab Kejadian (Safar at-Takwin) yakni salah satu Injil dan ditemukan pula dalam hadis Nabi Saw. yang sekiranya tidak ditemukan hadis tersebut, tentunya hal itu tidak akan terlintas dalam pemikiran pembaca Alquran. ${ }^{34}$

Menurutnya, ada pendapat lain yang dipilih oleh Ab Muslim sebagaimana dikatakan oleh ar-Râziy bahwa makna "wa khalaqa minhâ zawjahâ" itu adalah Allah ciptakan isteri Àdam itu dari jenisnya sendiri. Pengertian seperti ini ditemukan pada sejumlah ayat Alquran, yakni; Sûrah ar-Rûm ayat 21, Sûrah an-Nahl ayat 17, dan Sûrah asy-Syûrâ ayat 11. Dalam hal ini, termasuk pula apa yang dimaksudkan oleh Sûrah atTawbah ayat 128 dan Sûrah Àli 'Imrân ayat 164. ${ }^{35}$ Semua ayat ini bermakna bahwa pasangan-pasangan itu adalah dari jenisnya sendiri atau rasul yang diutus itu adalah sejenis dengan umat yang didatanginya.

Sayyid Quthb (w. 1386 H./1966 M.) mengatakan bahwa makna yang dimaksudkan dari ungkapan “wa khalaqa minhâ zawjahấ" adalah kemanusiaan. Dengan demikian dapat dipahami bahwa pasangan manusia itu adalah manusia sendiri. 36 
Menurutnya, selama ini terjadi kekeliruan yang menyakitkan, di mana terdapat sejumlah pandangan yang picik terhadap perempuan, mereka dianggap sumber kotoran dan najis serta asal-usul kejahatan dan bencana .37 Sebenarnya pasangan atau isteri itu dari jenis yang pertama, yaitu manusia juga yang punya fithrah dan tabiat, Allah ciptakan sebagai pasangannya, dan dari keduanya Allah perkembangbiakkan laki-laki dan perempuan yang banyak. Tidak ada perbedaan dalam asal-usul dan fithrah, yang membedakan mereka hanyalah kesiapan dan pelaksanaan tugas.

Kemudian Muhammad Husayn athThabâthabâ'iy (w. 1981 M.) menjelaskan bahwa ungkapan "wa khalaqa minhâ zawjahâ" merupakan kondisi pasangan atau isterinya itu dari jenisnya sendiri karena adanya kesamaan. Pribadi-pribadi yang diperkembangbiakkan itu, semuanya dikembalikan kepada mereka berdua yang serupa dan punya kesamaan tadi. Lafal " min" menunjukkan penciptaan (bukan dalam arti sebagian) dan ayat itu sendiri disetir kepada pengertian Sûrah ar-Rûm ayat 21, Srah anNahl ayat 17, dan Sûrah asy-Syûrâ ayat 11 . Sebagai bandingan dari ayat-ayat ini adalah Sûrah adz-Zâriyât ayat 49 "wa min kulli syay'in khalaqnâ zawjayn, yang dalam sebagain tafsir bahwa yang dimaksudkan dengan ayat ini adalah isteri Àdam itu diambil dari diri Àdam, sesuai dengan sebagian hadis yang menyatakan bahwa
Allah menciptakan isteri Àdam itu dari salah satu tulang rusuknya, yang tidak ditemukan dalilnya dari Alquran. ${ }^{38}$

Dari uraian terdahulu, diketahui bahwa para mufasir yang penafsiran mereka penulis kutip dalam tulisan ini sepakat bahwa yang dimaksud dengan ungkapan "wa khalaqa minhâ zawjahâ" adalah bahwa Allah swt. menciptakan pasangan "an-Nafs" itu dari jenisnya sendiri, yaitu makhluk yang punya kesamaan dan keserupaan yang disebut manusia.

Adapun penafsiran para mufasir yang menggunakan hadis yang menyatakan bahwa Hawwâ diciptakan oleh Allah dari tulang rusuk Àdam, dilihat dari konteks esensi hadis dianggap kurang relevan, karena Nabi Saw. sendiri tidak menegaskan bahwa sabdanya itu sebagai penafsiran terhadap Srah an-Nisâ ayat satu tersebut.

Para ulama ahli hadis, seperti alBukhâriy, Muslim, at-Turmudziy dan Ibnu Mâjah, juga tidak menempatkan hadis-hadis tersebut sebagai penafsir pada ayat satu Surah an-Nisa tersebut, terutama berkaitan dengan kejadian perempuan, lebih khusus lagi kejadian Hawwâ. Al-Bukhâriy memuatnya dalam anak judul Ahâdits alAnbiyâ yang menggambarkan bahwa hadis tersebut berkaitan dengan para nabi dan tiga anak judul berikutnya berkaitan dengan urusan kekeluargaan, yaitu nikah, menyusui dan cerai yang dari ketiga anak judul ini semakin jelas konteks hadis itu berkaitan 
dengan anjuran Nabi Muhammad Saw. agar para suami hendaknya bertindak arif dan bijaksana terhadap isteri-isteri mereka, karena mereka punya sifat dasar tertentu yang tidak dapat dengan mudah mengubahnya. Andaikan pengubahan itu dapat terjadi, maka itu merupakan perubahan yang semestinya tidak terjadi, karena perubahan dimaksud menghancurkan keutuhan rumah tangga, yaitu cerai.

Lebih khusus lagi, anak judul yang dikemukakan oleh Ibnu Mâjah, menempatkan hadis dimaksud sebagai alasan atau argumen yang diajukan oleh Imâm asy-Syâfi'i untuk memperkuat hadis lain yang membedakan cara membersihkan najis, karena air kencing anak laki-laki dan anak perempuan yang belum makan apa-apa selain susu.

Dari uraian tersebut dapat diketahui bahwa penggunaan hadis penciptaan Hawwâ dari tulang rusuk Àdam sebagai penafsir Surah an-Nisa ayat satu, merupakan kreasi para mufasir, bukan petunjuk langsung dari Rasulullah Saw., karena dalam kasus tertentu, seperti ketika ia menjelaskan pengertian "dzulm" ia dengan tegas menyatakan bahwa pemahaman para sahabat secara linguistik / lugawiy terhadap Surah al-An'âm ayat 82 itu tidak tepat dan secara lugas ia menyatakan bahwa yang dimaksud oleh ayat tersebut adalah apa yang terdapat pada Surah Luqmân ayat 13, yakni "syirk".
Dari kasus ini, penulis berpendapat, jika Rasulullah Saw. menyatakan secara tegas bahwa yang dimaksud dengan ungkapan "wa khalaqa minhâ zawjaha" adalah bahwa Allah swt. menciptakan Hawwâ dari tulang rusuk Àdam, maka tidak ada peluang lagi untuk mencari penafsiran yang lain dan harus diterima oleh seluruh umat Islam.

Di sisi lain, penafsiran hasil kreativitas para mufasir tersebut tidak didukung oleh adanya ayat yang lain, sementara ayat-ayat lainnya justeru menggambarkan bahwa ungkapan "min anfusikum" menunjukkan arti jenis yang sama, yaitu sama-sama manusia. Maksudnya bahwa pasangan atau isteri manusia itu dari jenis manusia itu sendiri.

Pendapat terakhir ini, berbeda dengan pendapat jumhur ulama sebelumnya cukup beralasan pula. Jika diteliti secara cermat penggunaan kata nafs yang terulang $295 \mathrm{kali}$ dalam berbagai bentuknya dalam al-Qur'an, tidak satupun dengan tegas menunjuk kepada Adam. Kata nafs kadang-kadang berarti "jiwa" (QS. al-Ma'idah/5 ayat 32), "nafsu" (QS. al-Fajr/89 ayat 27), "nyawa/roh" (QS. al-'Ankabut/29 ayat 57). Kata al-nafs alwâhidah sebagai "asal-usul kejadian" terulang lima kali tetapi itu semua tidak mesti berarti Adam, karena pada ayat lain, seperti QS. alSyu'ra/42 ayat 11 , nafs itu juga menjadi asalusul binatang. Kalau dikatakan al-nafs alwâhidah ialah Adam, berarti Adam juga 
menjadi asal-usul kejadian hewan dan tumbuh-tumbuhan.

Jika di perhatikan sekali lagi, maka pada dasarnya ayat ini menggunakan bentuk nakirah/indefinite "dari satu diri" (min nafsin), bukan dalam bentuk ma'rifah/definite (min al-nafs), berarti menunjukkan kekhususan (yufid al-takhshish) lalu diperkuat ( $t a^{\prime} k i d$ ) dengan kata "yang satu" (wahidah) sebagai shifat dari min nafsin. Semuanya ini menunjukkan kepada substansi utama (the first resource), yakni asal (unsur) kejadian Adam, bukan Adam-nya sendiri sebagai secondary resources. Di samping itu, seandainya yang dimaksud pada kata nafs ialah Adam, mengapa tidak digunakan kata wahidin dengan bentuk gender laki-laki (mudzakkar), tetapi yang digunakan kata wahidah dalam bentuk perempuan (mu'annats). Walaupun kita tahu bahwa kata nafs ${ }^{39}$ masuk kategori mu'annats sebagaimana beberapa ism 'alam lainnya tetapi dalam al-Qur'an sering dijumpai shifat itu menyalahi bentuk mawshuf-nya kemudian merujuk ke hakekat yang di-shifati, jika yang di-shifat-i itu hendak ditekankan oleh Si Pembicara (Mukhathab). ${ }^{40}$

Kata al-nafs al-wâhidah dalam ayat itu boleh jadi suatu genus dan salah satu speciesnya ialah Adam dan pasangannya (pair/zawj-nya) (QS. al-A'raf/7 ayat 189), sedangkan species lainnya ialah binatang dan pasangannya (QS. al-Syura/42 ayat 11) serta tumbuh-tumbuhan dan pasangannya (QS. Thaha/20 ayat 53).

Surah al-Nisa' di atas agaknya kurang relevan dijadikan dasar dalam menerangkan asal-usul kejadian manusia secara biologis, karena dilihat dari konteks (munasabah), ayat itu berbicara tentang tanggung jawab para wali terhadap orang di bawah perwaliannya. Ada ayat-ayat lain lebih khusus berbicara tentang asal-usul kejadian, seperti asal-usul manusia dari "air"/al-ma' (QS. al-Furqan/25 ayat 54), "air hina"/ma' in mahin (QS. al-Mursalat/77 ayat 20), dan "air yang terpancar"/ma'in dafiq (QS. alThariq/86 ayat 6), "darah"/'alaq (QS. al'Alaq/96 ayat 2), "saripati tanah"/sulalatin min thin (QS. al-Mu'minun/23 ayat 12), "tanah liat yang kering"/shalshalin min hama'in mahan (QS. al--Hijr/ 15 ayat 28), "tanah yang kering seperti tembikar"/shalshalin ka 'l-fakhkhar (QS. alRahman/55 ayat 15), "dari tanah"/min thin (QS. al-Sajdah/32 ayat 7), dan "diri yang satu"/nafs al-wâhidah (QS. al-Nisa'/4 ayat 1). Akan tetapi asal-usul kejadian manusia masih perlu diteliti lebih lanjut, yang mana asal-usul dalam arti ciptaan awal (production) dan mana asal-usul dalam arti ciptaan lanjutan (reproduction).

Ada kesulitan dalam memahami kisah asal-usul kejadian manusia dalam alQur'an karena ada loncatan atau semacam missing link dalam kisah-kisah tersebut. AlQur'an tidak menerangkan secara runtut dari 
A sampai Z, tetapi dari A meloncat ke $X$ dan Z. Apa yang terjadi antara $A$ dan $X$ atau $Z$ tidak dijelaskan. Al-Qur'an bercerita tentang asal-usul sumber manusia pertama dari "gen yang satu" (nafs al-wahidah), Gen yang melahirkan species makhluk biologis seperti jenis manusia, jenis binatang, dan jenis tumbuh-tumbuhan. Dalam komponen lain ayat-ayat berbicara tentang asal-usul manusia dalam konteks reproduksi, seperti pada QS. al-Mu'minun/23 ayat 12-14.

Ayat-ayat kejadian manusia dalam alQur'an tidak cukup kuat dijadikan alasan untuk menolak atau mendukung teori evolusi dan untuk hal ini masih perlu penelitian lebih lanjut. Terdapat beberapa ayat mengisyaratkan adanya makhluk sejenis manusia selain dan sebelum Adam; seperti pertanyaan malaikat yang bernada protes terhadap keinginan Tuhan untuk menciptakan khalifah di bumi yang mengkhawatirkan terjadinya pengulangan sejarah pertumpahan darah (QS. alBaqarah/2 ayat 30) dan penggunaan dlamir plural (khalaqa-kum) pada penciptaan manusia awal (QS. al-A'raf/7 ayat 11). Ayatayat itu dapat dihubungkan dengan kemungkinan adanya makhluk sejenis Adam pra Adam. Sementara banyak ayat mengisyaratkan manusia sebagai ciptaan yang unik (the unical creation), sebagaimana diuraikan terdahulu.

Konsep teologi yang menganggap Hawa/Eva berasal usul dari tulang rusuk
Adam membawa implikasi psikologis, sosial, budaya, ekonomi, dan politik. Informasi dari sumber-sumber ajaran agama mengenai asal usul kejadian perempuan belum bisa dijelaskan secara tuntas oleh ilmu pengetahuan. Kalangan feminis Yahudi dan Kristen cenderung mengartikan kisah-kisah itu sebagai simbolis yang perlu diberikan muatan makna lain.41 Pemahaman yang keliru mengenai asal-usul kejadian tersebut bisa melahirkan sikap ambivalensi di kalangan perempuan; di satu pihak ditantang untuk berprestasi dan mengembangkan karier agar tidak selalu menjadi beban lakilaki tetapi di lain pihak, ketika seorang perempuan mencapai karier puncak, keberadaannya sebagai perempuan shaleh dipertanyakan. Seolah-olah keberhasilan dan prestasi perempuan tidak cukup hanya diukur oleh suatu standar profesional tetapi juga seberapa jauh hal itu direlakan kaum laki-laki.

Kedua, persoalan kepemimpinan kaum Perempuan atas laki-laki. Adapun ayat yang berkaitan dengan laki-laki pemimpin perempuan adalah QS. Al-Nisa ayat 34, yaitu sebagai berikut:

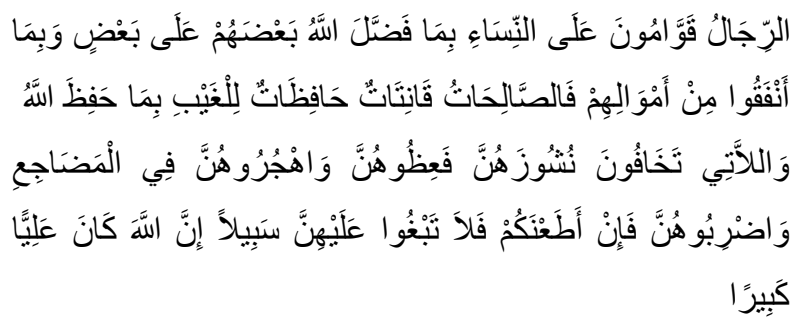

Al-Alusiy (217-270 H.) memberikan komentar bahwa laki-laki itu memimpin 
perempuan sebagaimana pemerintah memimpin rakyatnya dengan perintah, larangan dan sebagainya. ${ }^{42}$

Ath-Tusiy (385-460 H.) memulai komentarnya dengan mengemukakan latar belakang turunnya ayat (sabab an-nuzl) sebagai berikut:

“Al-Hasan, Qatâdah, Ibnu Jurayj, dan as-Suddiy meriwayatkan bahwa seorang suami menampar isterinya. Lalu si isteri itu datang kepada Nabi Saw. menuntut agar dilaksanakan qisâs, kemudian turunlah ayat yang berbunyi: "ar-rijâlu qawwâmna 'alâ annisâa".43

Selanjutnya ath-Thusiy menjelaskan makna ayat tersebut:

Laki-laki bertugas mendidik dan mengatur perempuan, karena kelebihan yang Allah berikan kepada mereka berupa akal dan pendapat (al-'aql wa ar-ra'y). Ia juga mengutip pendapat az-Zuhriy yang mengatakan: "Tidak ada qisâs antara suami dengan isterinya, selain menghilangkan nyawanya". Yang dimaksudkan dengan ungkapan "rajulun qayyimun, wa qawwâm, wa qiyâm" adalah bahwa mereka melaksanakan urusan perempuan agar menaati Allah dan menaati mereka. ${ }^{44}$

Az-Zamahsyariy (467-538 H.) menjelaskan:

Laki-laki itu menjaga para perempuan sebagai pemberi perintah atau larangan, sebagaimana pemerintah menjaga rakyatnya. Laki-laki mengawasi perempuan, karena kelebihan yang Allah berikan kepada mereka, bukan karena menguasai, dapat memberi dan memaksa. Ia mengutip sejumlah kelebihan yang Allah berikan kepada laki-laki atas perempuan, baik yang bersifat fisik, mental, maupun urusan keagamaan. Antara lain adalah: akal, mengambil keputusan, tekat, dan kemampuan menulis pada umumnya; mengendarai kuda dan memanah. Para nabi dan ulama serta pemimpin besar dan kecil dari laki-laki. Mereka yang disuruh berjihad, berkhutbah, i'tikâf, takbiran pada hari-hari tasyriq dan lain-lain. ${ }^{45}$

Abu Hayyân al-Andalusiy (654-745 H.) memulai komentarnya dengan mengemukakan latar belakang turunnya ayat yang lebih lengkap dari apa yang dikemukakan oleh ath-Thusiy.

Menurutnya, ada seorang perempuan yang telah ditampar oleh suaminya, perempuan itu lalu minta diputuskan hukuman untuk suaminya dan ditetapkanlah hukum qisâs. Akan tetapi, sebelum qisâs itu diberlakukan, turunlah ayat ini. Nabi Saw. pun lalu bersabda: "Anda menginginkan suatu perkara, namun Allah menghendaki perkara yang lain". Selanjutnya Abu Hayyân mengemukakan beberapa riwayat secara panjang lebar yang 
menyebutkan bahwa perempuan itu adalah Habibah binti Zayd bin Abi Zuhayr isteri ar-Rabi' bin 'Amr dan akhirnya hukuman qisâs itu ditiadakan. 46

Menurut Ibnu Katsir (705-774 H.) bahwa laki-laki itu pemimpin perempuan, pengatur, penentu (pembuat keputusan),dan pendidiknya jika perempuan itu bertindak tidak lurus. Bahkan laki-laki itu lebih baik dan lebih utama dari perempuan, karena itulah kenabian hanya diberikan kepada kaum laki-laki. ${ }^{47}$ Sebagai argumen pendapatnya ini, ia mengemukakan hadis Nabi Saw. yang diriwayatkan oleh alBukhâriy dari 'Abd ar-Rahmân bin Abi Bakrah dari Ayahnya yang artinya: "Suatu bangsa tidak akan memperoleh keberuntungan (jika) menyerahkan urusan mereka kepada seorang perempuan". 48

Imâm as-Suythiy (849-911 H.) dan alMahalliy (791-864 H.) menjelaskan bahwa laki-laki itu pemegang kekuasaan atas perempuan, mendidik mereka dan dapat menindak mereka. ${ }^{49}$ Abu as-Su'd (893-982 H.) menjelaskan bahwa laki-laki itu pemegang tampuk pemerintahan terhadap perempuan, sebagaimana pemegang tampuk pemerintahan terhadap rakyatnya. Dalam hal ini, mereka diberi kelebihan atas perempuan. 50

$$
\text { Al-Qâsimiy (1866-1914 M.) }
$$

menjelaskan bahwa ungkapan "qawwâmun" itu bentuk jamak (plural) dari qawwâm dalam arti laki-laki itu adalah orang yang tegak untuk mengatur kemaslahatan dan pendidikan perempuan, mengatur mereka dengan memerintah dan melarang sebagaimana pemerintah mengatur rakyatnya. ${ }^{51}$

Ahmad Musthafâ al-Marâgiy (18831952 M.) menjelaskan bahwa laki-laki itu memelihara dan melindungi perempuan. Lebih tegas lagi, berkaitan dengan kepemimpinan laki-laki atas perempuan, ia menjelaskan:

Orang yang dipimpin melaksanakan apa yang diinginkan dan dipilih oleh pemimpinnya. Makna kepemimpinan itu hanya memberi petunjuk dan mengawasi terhadap apa yang diperintahkannya dan memperhatikan apa yang dikerjakannya. Karena itu, perempuan bertugas menjaga rumah suaminya, tidak berpisah dengan suaminya (tidak meninggalkan rumah) tanpa izin suaminya, sekalipun untuk mengunjungi keluarga dekat. 52

Muhammad 'Aliy as-Syâbûniy menjelaskan bahwa laki-laki itu dapat memerintah, melarang, memberi nafkah, dan arahan, sebagaimana pemerintah memerintah rakyatnya. 53

Abu Bakr Jâbir al-Jazâ'iriy, penasihat Mesjid Nabawiy di Madinah menjelaskan bahwa "kata qawwâmn itu adalah bentuk jamak (plural) dari kata qawwâm, yang berarti orang yang tegak atas sesuatu dalam 
hal pemeliharaan, perlindungan, dan perbaikan". .54

Setelah mengemukakan sebab turunnya ayat ini dan menjelaskan gagalnya pelaksanaan qisâs ia mengomentari ayat ini sebagai berikut:

Laki-laki itu pemimpin perempuan. Kita menginginkan satu perkara, namun Allah menghendaki perkara yang lain. Apa yang Allah kehendaki adalah lebih baik dan menerima ketentuan Allah bahwa laki-laki itu selamanya menjadi pemimpin perempuan. Ia memeliharanya, mendidiknya, dan memperbaikinya dengan apa yang Allah anugerahkan kepada-Nya berupa akal yang lebih sempurna dari akal perempuan, pengetahuan yang lebih banyak dari pengetahuan perempuan pada umumnya, pandangan yang jauh ke depan dalam berbagai urusan baik persiapan maupun menentukan sasarannya. Lebih dari itu semua, lakilaki membayar mahar sementara perempuan tidak membayarnya, lakilaki berkewajiban memberi nafkah sementara perempuan tidak berkewajiban untuk itu. Mengingat bahwa laki-laki berkewajiban menjadi pemimpinperempuan secara syar'iy, maka ia berhak memukul isterinya namun tidak sampai berakibat luka atau merusak anggota badan. Pukulan tersebut bersifat persuasif dengan tujuan mendidik. 55

Wahbah az-Zuhayliy, Ketua Jurusan Fiqh Islam dan Mazhab-mazhabnya di Universitas Damaskus, menjelaskan:

Laki-laki itu mengurusi, memelihara atau menjaga dan memimpin perempuan berdasarkan haknya, mendidik dan dapat mengambil tindakan terhadap perempuan. Yang dimaksudkan dengan kepemimpinan di sini adalah kepemimpinan dalam urusan keluarga dan rumah tangga dan tidak berlaku untuk urusan kebatilan. Dalam hal ini, perempuan tidak boleh menaati laki-laki untuk melakukan kebatilan. ${ }^{56}$

Ibnu Fâris mengatakan bahwa kata yang akar katanya terdiri atas huruf-huruf "qâf, wâww, dan mim" mempunyai dua arti dasar, yaitu: "kumpulan orang" dan "berdiri tegak atau tekat" ${ }^{\prime 5}$ Berkaitan dengan ayat yang sedang ditafsirkan ini, lebih tepat untuk pengertian kedua.

Menurut Ibnu Mandzûr kata "qawwâmûn" berasal dari kata "qiyâm" yang berarti "'azm", yakni tekat; dapat pula berarti "al-muhâfadzah wa al-Islâh" yakni pemeliharaan dan perbaikan. Termasuk pengertian inilah firman Allah "ar-Rijâl qawwâmna 'alâ an-Nisâ" dan firman Allah "illâ mâ dumta 'alayhi qấiman" dalam arti "mulâziman muhâfidzan", yakni melazimi pemeliharaan; dan dapat pula bermakna "alwuqf wa ats-tsubt", yakni berdiri dan tetap. .58 
Lebih lanjut, Ibnu Mandzûr menjelaskan yang dimaksud dengan ayat tersebut bahwa laki-laki melaksanakan urusan isterinya dan keperluan isterinya itu kepadanya. Dengan demikian, laki-laki itu membebani dirinya dengan urusan-urusan perempuan dan memperhatikan kondisi mereka. ${ }^{59}$

Ar-Râgib al-Ashfahâniy (w. 425 H.) menjelaskan bahwa kata "qấ'im" yang bentuk plural (jamak)nya "qiyâm" ada beberapa macam pengertiannya: "qiyâm li asy-syay'i" berarti mengawasi dan menjaga sesuatu; dan "qiyâm 'alâ" berarti tekat untuk melaksanakan sesuatu". Menurutnya, ayat yang ditafsirkan ini termasuk dalam pengertian yang pertama, yaitu mengatur dan memilih seseorang. 60

Dari uraian-uraian terakhir ini dapat diambil pengertian bahwa yang dimaksud dengan ungkapan "ar-Rijâlu qawwâmna 'alâ an-Nisâ" itu adalah bahwa laki-laki (suami) itu berdiri tegak dan bertekat untuk memilih dan mengatur serta melaksanakan berbagai urusan dan keperluan isterinya dalam upaya memelihara dan memperbaiki keadaan isterinya itu. Dari pengertian ini, tergambar bahwa ayat ini berkaitan dengan kehidupan suami isteri dalam rumah tangga. Hal ini diperkuat lagi oleh adanya peristiwa yang melatarbelakangi turunnya ayat tersebut.

Hal ini juga dipertegas oleh $\mathrm{M}$. Quraish Shihab. Secara ringkan ia mengatakan :
Harus diakui bahwa ada sementara ulama yang menjadikan firman Allah dalam Surah an-Nisâ ayat 34 yang berarti "lelaki-lelaki adalah pemimpin perempuan-perempuan"... sebagai bukti tidak bolehnya perempuan terlibat dalam persoalan politik. Karena --kata mereka--kepemimpinan berada di tangan mereka. Pandangan ini tidak sejalan dengan makna sebenarnya yang diamanatkan oleh ayat ini. Ayat ini berbicara tentang kepemimpinan lelaki (dalam hal ini suami) terhadap seluruh keluarganya dalam bidang kehidupan rumah tangga. Kepemimpinan ini pun tidak mencabut hak-hak isteri dalam berbagai segi, termasuk dalam hak pemilikan harta pribadi dan hak pengelolaannya walaupun tanpa persetujuan suami.

Kenyataan sejarah menunjukkan sekian banyak di antara kaum perempuan yang terlibat dalam soal-soal politik praktis. Ummu Hâni misalnya, dibenarkan sikapnya oleh Nabi Muhammad Saw. ketika memberikan jaminan keamanan kepada sementara orang musyrik (jaminan keamanan merupakan salah satu aspek bidang politik). Bahkan isteri Nabi Muhammad Saw. sendiri, yakni 'À'isyah ra., memimpin langsung peperangan melawan 'Aliy bin Abi Thâlib yang ketika itu menduduki jabatan Kepala Negara. Isu terbesar 
dalam peperangan tersebut adalah soal suksesi setelah terbunuhnya Khalifah Ketiga, 'Utsmân bin 'Affân ra. ${ }^{61}$

Uraian ringkas yang dikemukakan oleh M. Quraish Shihab ini membuka wawasan baru dalam penafsiran Alquran, terutama berkaitan dengan laki-laki pemimpin perempuan, yang menurutnya terbatas dalam kehidupan suami isteri atau lebih luas lagi kehidupan rumah tangga dan keluarga.

Ketiga, Perempuan dan Dosa Warisan. Konsep teologi yang juga memberikan citra negatif kepada kaum perempuan ialah anggapan bahwa Hawa menjadi penyebab tergelincirnya Adam dari Sorga ke planet bumi. Karena rayuannya, Adam lengah lalu memakan buah terlarang menyebabkannya terlempar ke bumi. Akhirnya, kaum perempuan harus menanggung akibat lebih besar, seperti yang dapat dilihat dalam Kitab Talmud dan Bibel.

Dalam Agama Yahudi, asal-usul terjadinya dosa asal (original sin) juga lebih banyak dipersalahkan kaum perempuan. Bahkan kalangan misogyny menganggap perempuan sebagai "setan betina" (female demon) yang harus selalu diwaspadai.

Dalam Kitab Talmud (Eruvin 100b) disebutkan bahwa akibat pelanggaran Hawa/Eva di Sorga maka kaum perempuan secara keseluruhan akan menanggung 10 beban penderitaan: a. Perempuan akan mengalami siklus menstruasi, yang sebelumnya Hawa/ Eva tidak pernah mengalaminya.

b. Perempuan yang pertama kali melakukan persetubuhan akan mengalami rasa sakit.

c. Perempuan akan mengalami penderitaan dalam mengasuh dan memelihara anak-anaknya. Anakanak membutuhkan perawatan, pakaian, kebersihan, dan pengasuhan sampai dewasa. Ibu merasa risih manakala pertumbuhan anakanaknya tidak seperti yang diharapkan.

d. Perempuan akan merasa malu terhadap tubuhnya sendiri.

e. Perempuan akan merasa tidak leluasa bergerak ketika kandungannya berumur tua.

f. Perempuan akan merasa sakit pada waktu melahirkan.

g. Perempuan tidak boleh mengawini lebih dari satu laki-laki.

h. Perempuan masih akan merasakan hubungan seks lebih lama sementara suaminya sudah tidak kuat lagi.

i. Perempuan sangat berhasrat melakukan hubungan seks terhadap suaminya, tetapi amat berat menyampaikan hasrat itu kepadanya.

j. Perempuan lebih suka tinggal di rumah. ${ }^{62}$ 
Mungkin banyak kaum perempuan dewasa ini tidak sadar kalau poin pertama sampai terakhir bukan sekedar peristiwa alami, tetapi oleh orang-orang yang mempercayai kitab itu diyakini sebagai bagian dari "kutukan" Tuhan terhadap kesalahan Hawa.

Sedangkan kutukan yang ditimpakan kepada laki-laki, dan ini menarik untuk diperhatikan, adalah sebagai berikut:

a. Sebelum terjadi kasus pelanggaran (spiritual decline) postur tubuh lakilaki lebih tinggi dari pada bentuk normal sesudahnya.

b. Laki-laki akan merasa lemah ketika ejakulasi.

c. Bumi akan ditumbuhi banyak pohon berduri.

d. Laki-laki akan merasa susah dalam memperoleh mata pencaharian.

e. Laki-laki pernah makan rumput di lapangan rumput bersama binatang ternak, tetapi Adam memohon kepada Tuhan agar kutukan yang satu ini dihilangkan.

f. Laki-laki akan makan makanan dengan mengeluarkan keringat di alisnya.

g. Adam kehilangan ketampanan menakjubkan yang telah diberikan oleh Tuhan kepadanya.

h. Ditinggalkan oleh ular yang sebelumnya telah menjadi pembantu setia laki-laki. i. Adam dibuang dari taman sorga dan kehilangan status sebagai penguasa jagat raya.

j. Laki-laki diciptakan dari debu dan akan kembali menjadi debu. Ia ditakdirkan untuk mati dan dikubur. ${ }^{63}$

Kutukan yang ditimpakan kepada kaum laki-laki, selain lebih lunak kutukan itu juga langsung atau tidak langsung menimpa kaum perempuan. Sebaliknya, kutukan terhadap perempuan lebih berat dan monumental serta hanya dialaminya sendiri, tidak dialami kaum laki-laki.

Dalam Bibel juga dipersepsikan bahwa kaum laki-laki pantas memiliki superioritas di atas perempuan, sebaliknya kaum perempuan pada tempatnyalah mengabdikan diri kepada kaum laki-laki, karena selain diciptakan dari tulang rusuk Adam dan untuk melengkapi kesenangan Adam, juga dianggap penyebab langsung jatuhnya Adam dari syorga, seperti diungkapkan dalam Kitab Kejadian (3:12):

"Manusia itu menjawab: "Perempuan yang kamu tempatkan di sisiku, dialah yang memberi dari buah pohon itu kepadaku, maka kumakan".64

Sebagai sanksi terhadap kaum perempuan antara lain dikatakan dalam Kitab Kejadian (3:16)

"FirmanNya kepada perempuan itu: "Susah payahmu waktu mengandung akan kubuat sangat banyak, dengan kesakitan engkau akan 
melahirkan anakmu; namun engkau akan berahi kepada suamimu dan ia akan berkuasa atasmu." 65

Jika doktrin-doktrin tersebut dilihat dalam perspektif sejarah, maka Islam adalah suatu sistem nilai yang progressif pada zamannya. Ajaran-ajarannya yang kontroversi ketika itu tidak hanya dapat ditawarkan (accessible) tetapi juga dapat diterima (acceptable) dalam kurun waktu yang singkat. Dapat dibandingkan ajaran Bibel baru populer setelah 'Isa/Yesus meninggal, sedangkan Nabi Muhammad sempat menyaksikan ajarannya dianut di sekitar Timur-Tengah.

Di antara kutukan perempuan yang paling monumental ialah menstruasi. Teologi menstruasi ini kemudian menyatu dengan berbagai mitos yang berkembang dari mulut ke mulut (oral tradition) ke berbagai belahan bumi.

Teologi menstruasi dianggap berkaitan dengan pandangan kosmopolitan terhadap tubuh perempuan yang sedang menstruasi. Perilaku perempuan di alam mikrokosmos diyakini mempunyai hubungan kausalitas dengan alam makrokosmos. Peristiwa-peristiwa alam seperti bencana alam, kemarau panjang dan berkembangnya hama penyebab gagalnya panen petani dihubungkan dengan adanya yang salah dalam diri perempuan.

Darah menstruasi (menstrual blood) dianggap darah tabu (menstrual taboo) dan perempuan yang sedang menstruasi menurut kepercayaan agama Yahudi harus hidup dalam gubuk khusus (menstrual huts), suatu gubuk khusus dirancang untuk tempat hunian para perempuan menstruasi atau mengasingkan diri di dalam goa-goa, tidak boleh bercampur dengan keluarganya, tidak boleh berhubungan seks, dan tidak boleh menyentuh jenis masakan tertentu. Yang lebih penting ialah tatapan mata (menstrual gaze) dari mata perempuan sedang menstruasi yang biasa disebut dengan "mata iblis" (evil eye) harus diwaspadai, karena diyakini bisa menimbulkan berbagai bencana. Perempuan harus mengenakan identitas diri sebagai isyarat tanda bahaya (signals of warning) manakala sedang menstruasi, supaya tidak terjadi pelanggaran terhadap menstrual taboo. ${ }^{66}$ Dari sinilah asalusul penggunaan kosmetik yang semula hanya diperuntukkan kepada perempuan sedang menstruasi. Barang-barang perhiasan seperti cincin, gelang, kalung, giwang, anting-anting, sandal, selop, lipstik, shadow, celak, termasuk cadar/jilbab ternyata adalah menstrual creations. ${ }^{67}$

Upaya lain dalam mengamankan tatapan "mata iblis" ialah dengan menggunakan kerudung/cadar (hoods/veils) yang dapat menghalangi tatapan mata tersebut. Kalangan antropolog berpendapat menstrual taboo inilah yang menjadi asal-usul penggunaan kerudung atau cadar. Cadar atau semacamnya bukan berawal dan 
diperkenalkan oleh Agama Islam dengan mengutip "ayat-ayat jilbab"68 dan haditshadits tentang aurat. Jauh sebelumnya sudah ada konsep kerudung/cadar yang diperkenalkan dalam Kitab Tawrat dan Kitab Injil. Bahkan menurut Epstein, ketentuan penggunaan cadar sudah dikenal dalam Hukum Kekeluargaan Asyiria (Assyrian Code):

The tradition that women veil themselves when they go out in public a very old in the orient. Probably the first reference is to be found in the Assyirian Code, where it a ruled that wives, daughters, widows, when, going out in public, must be veiled. 69

(Tradisi penggunaan kerudung ke tempat-tempat umum sudah berlangsung sejak dahulu kala di Timur. Kemungkinan referensi paling pertama ditemukan ialah di dalam hukum Asyiria, yang mengatur bahwa: isteri, anak perempuan, janda, bilamana pergi ke tempat-tempat umum harus menggunakan kerudung).

Asal-usul penggunaan cadar atau kerudung dan berbagai macam kosmetik lainnya, menurut kalangan antropologis, berawal dari mitos menstrual taboo, yaitu untuk mencegah "si mata Iblis" dalam melakukan aksinya. ${ }^{70}$

Kutukan kepada kaum perempuan selanjutnya adalah menstruasi atau dalam literatur Islam disebut haydl.71 Dalam alQur'an hanya disebutkan empat kali dalam dua ayat; sekali dalam bentuk fi'l mudlari/present and future (yahidl) dan tiga kali dalam bentuk ism mashdar (al-mahidl). ${ }^{72}$

Dari segi penamaan saja, kata haydl sudah lepas dari konotasi teologis seperti agama-agama dan kepercayaan sebelumnya. Masalah haydl dijelaskan dalam Q., s. alBaqarah/1:222:

Mereka bertanya kepadamu (Muhammad) tentang haidh. Katakanlah: "Haydl itu adalah 'kotoran' oleh karena itu hendaklah kamu menjauhkan diri dari perempuan di waktu haydl; dan janganlah kamu mendekati mereka sebelum mereka suci. Apabila mereka telah suci, maka campurilah mereka di tempat yang diperintahkan Allah kepadamu. Sesungguhnya Allah menyukai orang-orang yang taubat dan menyukai orang-orang yang mensucikan diri.

Sebab turunnya ayat itu dijelaskan dalam hadits riwayat Imam Ahmad dari Anas, bahwa bilamana perempuan Yahudi sedang haydl, masakannya tidak dimakan dan tidak boleh berkumpul bersama keluarga di rumahnya. Salah seorang sahabat menanyakan hal itu kepada Nabi, kemudian Nabi berdiam sementara maka turunlah ayat tersebut di atas. Setelah ayat itu turun, Rasulullah bersabda "lakukanlah segala sesuatu (kepada isteri yang sedang haydl) kecuali bersetubuh". Pernyataan Rasulullah ini sampai kepada orang-orang Yahudi, lalu orang-orang Yahudi dan mantan penganut Yahudi seperti shock mendengarkan pernyataan tersebut. Apa yang selama ini 
dianggap tabu tiba-tiba dianggap sebagai "hal yang alami" (adzan). Kalangan mereka bereaksi dengan mengatakan apa yang disampaikan oleh laki-laki itu (Rasulullah) adalah suatu penyimpangan dari tradisi besar kita. Usayd ibn Hudlayr dan Ubbad ibn Basyr melaporkan reaksi tersebut kepada Rasulullah; lalu wajah Rasulullah berubah karena merasa kurang enak terhadap reaksi tersebut. ${ }^{73}$

Rasulullah dalam banyak kesempatan menegaskan kebolehan melakukan kontak sosial dengan perempuan haid. Rasulullah kembali menegaskan bahwa: "Segala sesuatu dibolehkan untuknya kecuali kemaluannya (faraj)", "Segala sesuatu boleh untuknya kecuali bersetubuh (al-jima')". Bahkan Rasulullah seringkali mengamalkan kebolehan itu dalam bentuk praktek. Riwayat lain yang secara demonstratif disampaikan 'A'isyah, antara lain, 'A'isyah pernah minum dalam satu bejana yang sama dalam keadaan haydl, juga pernah menceritakan Rasulullah melakukan segala sesuatu selain bersetubuh (jima') sementara dirinya dalam keadaan haid, juga darah haydl dan bekasnya yang terdapat dalam pakaian 'A'isyah; sama sekali Rasulullah tidak memperlihatkan perlakuan taboo terhadapnya. ${ }^{74}$ Jika diteliti lebih cermat, meanstream ayat di atas sesungguhnya bukan lagi haydl-nya itu sendiri tetapi pada al-mahidl-nya atau "tempat" keluarnya darah itu (mawdhi 'alhaydl), karena Tuhan menggunakan kata al- mahidl, bukan al-haydl. Walaupun kedua kata itu sama-sama dalam bentuk mashdar/verbal noun tetapi yang pertama menekankan "tempat" haid (mawdhi 'alhaydl) sedangkan yang kedua menekankan "waktu" dan "zat" haid ('ayn al-haydl) itu sendiri.

Banyak mufassir menyamakan atau tidak menegaskan perbedaan pengertian kedua istilah tersebut. Pada hal menyamakan atau membedakan pengertian tersebut masing-masing mempunyai makna yang berbeda, bahkan lebih jauh akan berimplementasi kepada persoalan hukum. Kalau al-mahidl diartikan sama dengan alhaydl, maka ayat tersebut berarti jauhilah perempuan itu pada waktu haydl artinya dilarang bergaul dan bersenang-senang, dan ini jelas menyalahi struktur makna yang dikehendaki Sang Mukhathab. Akan tetapi kalau yang dimaksud ayat itu ialah al-mahidl dalam arti mawdhi 'al-haydl, maka ayat itu berarti jauhilah tempat haydl dari perempuan itu. Penggunaan logika yang kedua ini menjadi jelas tanpa harus lagi ada "penghapusan" (nasakh) atau pengkhususan (takhshish). Kalau yang dimaksud al-mahidl yakni al-haydl maka akan menimbulkan kejanggalan dalam pengertian, karena yang bermasalah (adzan) 75 dalam lanjutan ayat itu ialah waktu haid (zaman al-haydl), bukan tempat haid (mawdhi' al-haydl), jadinya tidak logis dalam pengertian (ghayr ma'qul alma'na) karena sesungguhnya yang 
bermasalah (adzan) ialah mawdhu'-nya. Haydl itu sendiri bukan adzan karena haydl hanya di-'ibirah-kan dengan darah yang khusus.

Imam al-Razi dalam tafsirnya memberikan alternatif lain dengan mengatakan bahwa kalimat al-mahidl yang pertama berarti al-haydl, sedangkan yang kedua berarti tempat haid. ${ }^{76}$ Implementasi dari pengertian ini ialah persoalan haid sebagaimana yang ditanyakan sahabat Nabi dan sekaligus menjadi sabab nuzul ayat itu hanyalah persoalan fisik-biologis, tempat keluarnya darah haidh itu bukan persoalan tabunya darah haid seperti yang dipersepsikan oleh umat-umat terdahulu.

Perintah untuk "menjauhi" (fa'tazilu) dalam ayat di atas bukan berarti menjauhi secara fisik (li al-tab'id) tetapi memisahkan atau menghindarkan diri untuk tidak berhubungan langsung (i tizal). Sedangkan darah haid disebut al-adzan karena darah tersebut adalah darah tidak sehat dan tidak diperlukan lagi oleh organ tubuh perempuan. Bahkan kalau darah itu tinggal di dalam perut akan menimbulkan masalah, karena itulah disebut adzan. Mengenai pembersihan diri (thaharah) ${ }^{77}$ dari haydl, dalam Islam tidak pula dikenal adanya upacara ritual khusus seperti dalam agama Yahudi dan kepercayaan-kepercayaan sebelumnya. Jumhur ulama berpendapat bahwa sesudah hari ketujuh ${ }^{78}$ ia sudah dapat dianggap bersih setelah mandi, kecuali Abu
Hanifah berpendapat tidak harus mandi tapi cukup membersihkan tempat keluarnya darah haid dan juga tidak perlu menunggu tujuh hari. Sekalipun kurang tujuh hari kalau sudah merasa bersih sudah dapat melakukan ibadah secara rutin. ${ }^{79}$

Dari gambaran tersebut di atas dapat dipahami bahwa ajaran Islam tidak menganut faham menstrual taboo, sebaliknya berupaya mengikis tradisi dan mitos masyarakat sebelumnya yang memberikan beban berat terhadap kaum perempuan. Seperti mitos tentang perempuan haid seolah-olah ia tidak dipandang dan diperlakukan sebagai manusia, karena selain harus diasingkan juga harus melakukan berbagai kegiatan ritual yang berat.

\section{KESIMPULAN}

Seperti kita ketahui, tidak satu ayat pun dalam al-Qur'an yang menampakkan misogyny atau bias gender. Semua ayat yang membicarakan tentang Adam dan pasangannya, sejak di surga hingga turun ke bumi, selalu menekankan kedua belah pihak dengan menggunakan kata ganti untuk dua orang (humâ ataupun kumâ). Disamping itu, bukan pasangan Adam yang disalahkan, melainkan syetan yang dikatakan menggoda keduanya hingga memakan buah dari pohon keabadian.

Di muka bumi, baik laki-laki maupun perempuan diposisikan setara. Derajat mereka ditentukan bukan oleh jenis kelamin, 
tetapi oleh iman dan amal shaleh masingmasing. Sebagai pasangan hidup, laki-laki diibaratkan seperti pakaian bagi perempuan, dan begitu pula sebaliknya.

Namun dalam kehidupan rumahtangga, masing-masing mempunyai peran tersendiri dan tanggung-jawab berbeda, seperti lazimnya hubungan antar manusia.

Dalam kehidupan bermasyarakat, berbangsa dan bernegara, laki-laki dan perempuan dituntut untuk berperan dan berpartisipasi secara aktif, melaksanakan amar ma'ruf dan nahi munkar serta berlomba-lomba dalam kebaikan.

\section{Endnotes:}

1 Mansour Fakih, Analisis Gender dan Transformasi Sosial, (Yogyakarta: Pustaka Pelajar,1996), 11-20

2 Diantara bentuk penolakan Riffat Hasan terhadap konsep bias gender adalah isu penciptaan perempuan yang ada hingga sekarang. Karena menurutnya secara filosofis maupun teologis konsep ketidakadilan atau ketidaksetaraan laki-laki dan perempuan berakar dari konsep penciptaan perempuan ini. Lihat Riffat Hasan, "Teologi Perempuan dalam Tradisi Islam", dalam Jurnal Ulumul Qur'an No. 4, Vol. I., tahun 1990;

3 Diantara karya Fatima Mernissi adalah Women's Rebellion $\mathcal{E}$ Islamic Memory (Pemberontakan Wanita Peran Intelektual Kaum Wanita Dalam Sejarah Muslim). Buku ini menguraikan fenomena ketidakadilan sosial dan budaya yang dihadapi perempuan dinegara-negara muslim. Mernissi lebih banyak mengkaji isu-isu fiqh, masalah kesehatan, politik dan peranan sosial yang dipandang merugikan perempuan. Sebagai justifikasi atas idenya tentang kesetaraan gender, dia memaparkan kisah-kisah kepahlawanan para perempuan sejak masa Sahabat dan peran sosial mereka. Buku lainnya Islam and Democracy, Fear of the Modern World (Islam dan Demokrasi:
Antologi Ketakutan). Mernissi menguraikan sejarah hitam peradaban Islam yang dipenuhi dengan pembunuhan politik, karena ketakutan para penguasa terhadap kebebasan berfikir. Buku ini juga menganalisis ketakutan di kalangan umat saat ini untuk membahas wacana demokrasi dan hak asasi manusia yang disebabkan adanya trauma sejarah dalam menempatkan perempuan di balik jilbab dan temboktembok pergundikan.

4 Diantara karya Leila Ahmed adalah Women and Gender in Islam: Historical Roots of a Modern Debate" (Wanita dan Gender dalam Islam: Akar-akar Historis Perdebatan Modern). Dalam bukunya ini, Leila menguraikan tentang akar-akar sejarah yang menjadi perdebatan hingga kini tentang pandangan Islam terhadap perempuan. Pembahasan buku ini dimulai dari kondisi kawasan Timur Tengah sebelum Islam, zaman kedatangan Islam dan penghargaannya terhadap perempuan. Selain itu juga dibahas masalah penafsiran dan kejumudan Islam abad pertengahan, sehingga munculnya wacana perubahan sosial dan intelektual berkenaan dengan hak dan kebebasan perempuan.

5 Lihat misaslnya Frederick Engels, The Origin of Family Private Property and State, (New York: International Publisher Company, 1976). Buku ini banyak mengilhami para feminis marxis dan sosialis di dalam memberikan solusi terhadap gender stereotyping di dalam masyarakat.

6 John M.Echols dan Hassan Shadily, Kamus Inggeris Indonesia, (Jakarta: Gramedia, cet. XII, 1983), hlm. 265

7 Victoria Neufeldt (ed.), Webster's New World Dictionary, (New York: Webster's New World Cleveland, 1984), hlm.561. Bandingkan dengan kamus Oxford yang mendefinisikan gender sebagai "a grammatical classification of objects roughly corresponding to the two sexes and sexlessness, property of belonging to such a class". Lihat C.T. Onionss (ed.), The Word Dictionary of English Etymology, (Oxford: Oxford at the Clarendon Press, 1979), hlm. 2

8 Hilary M. Lips, Sex $\mathcal{E}$ Gender an Introduction, (California, London, Toronto: Mayfield Publishing Company, 1993), hlm. 4.

9 Linda L. Lindsey, Gender Roles a Sociological Perspective, (New Jersey: Prentice Hall, 1990), hlm. 2. 
10 HLM.T. Wilson, Sex and Gender, Making Cultural Sense of Civilization, (Leiden, New York, Kobenhavn, Koln: EJ. Brill, 1989), hlm. 2.

11 Elaine Showalter (Ed.), Speaking of Gender, (New York \& London: Routledge, 1989), hlm. 3.

12 Kantor Menteri Negara Urusan Peranan Wanita, Buku III: Pengantar Teknik Analisa Jender, 1992, hlm. 3.

13 John M. Echols dan Hasan Shadily, Kamus Inggris Indonesia (Jakarta: Gramedia cetakan XXIII, 1996), hal. 265

14 Term ini dipakai Freire untuk menggambarkan kondisi sosial masyarakat yang pasif dan naif dalam menghadapi dan menaggapi persoalan hidup dengan cara pandang yang sangat dangkal dalam memaknai problem yang dihadapi.

15 http://www.paramadina.com

16 Hilary M. Lips, Sex and Gender: An Introduction (California: Mayfield Publishing Company, 2001), hlm. 4.

17 Nasaruddin Umar, Argumen Kesetaraan Jender (Jakarta: Paramadina, 2001), hal. 34.

18 Riffat Hasan memparmasalahkan, mengapa selalu dikatakan Adam wa zawj, sekiranya Adam laki-laki maka kata paling tepat digunakan ialah kata zawjahlm. (Lihat Riffat Hasan, "Teologi Perempuan dalam Tradisi Islam," dalam Ulumul Qur'an, Vol.1, 1990/1410 HLM., hlm. 51). Akan tetapi alasan ini lemah, karena kata zawj tidak mesti berarti isteri, dan tidak mesti memakai huruf ta marbutah (zawjah) sebagai simbol perempuan (muannats) untuk menunjukkan makna isteri, karena yang ditekankan pada ayat ini ialah pasangan (pair), seperti binatang dan tumbuh-tumbuhan yang berpasang-pasangan (Q., s. Thaha/20:53 dan s. al-Syura/42:11). Lagi pula kata ganti (dlamir) yang merujuk ke Adam semuanya menggunakan dhamir mudzakkar, di antaranya paling tegas ialah uskun anta wa zawjuk-a 'l-jannah (Q., s. al-Baqarah/2:35 dan s. al-A'raf/7:19). Kata uskun sudah cukup mengisyaratkan Adam sebagai mudzakkar tetapi diperkuat (ta'kid) dengan kata anta, kata ganti untuk orang pertama tunggal laki-laki.

19 Asy-Syaykh ath-Tâ'ifah Abi Ja'far Muhammad bin al-Hasan ath-tusiy, AtTibyân fi Tafsir al-Qur'ân, Jilid 3, dinotasi oleh Ahmad Hâsib Qa‘ir al-'Àmiliy, (T. t.: Maktabah al-' Àlam al-Islâmiy, t. t.), hlm. 99.
20 Imâm $\mathrm{Ab}$ al-Qâsim Jârullâh Mahmd bin 'Umar az-Zamahsyariy, Al-Kasysyâf 'an Haqâ'iq Gawâmi at-Tanzil wa 'Uyn al-Aqâwil fi Wujh at-Ta'wil, Juz 1, (Beirt: Dâr al-Kutub al'Ilmiyyah, 1415 H./1995 M.), hlm. 451.

$21 \quad$ Ibid

22 Ibid.

23 Muhammad bin Yusuf yang terkenal dengan Abu Hayyân al-Andalusiy, Tafsir al-Bahr alMuhith, Jilid 3, (Beirt: Dâr al-Fikr, 1983 M./1403 H.), Cet. ke-2, hlm. 154.

\section{$24 \quad$ Ibid}

25 Al-Hâfidz 'Imâd ad-Din Ab al-Fidâ Ismâ'il bin Katsir al-Qusyayriy ad-Dimasyqiy, Tafsi al-Qur'ân al-'Adzim, Juz 1, (Semarang: Toha Putra, t. t.), hlm. 448

26 Al-'Allâmah Jalâl ad-Din Muhammad bin Ahmad al-Mahalliy dan Jalâl ad-Din 'Abd arRahmân bin Abi Bakr as-Suythiy, Tafsir alQur'ân al-Karim (Tafsir Jalâlayn), Juz 1, (Surabaya: al-Maktabah as-Saqâfiyyah, 1345 H.), hlm. 70.

$27 \mathrm{Ab}$ as-Su'd, Tafsir Abi as-Su'd (Irsyâd al-'Aql as-Salim ilâ Mazâyâa al-Kitâb al-Karim), Juz 1, (T.T.: Dâr al-Fikr, t. t.), hlm. 476.

28 Muhammad Jamâl ad-Din al-Qâsimiy, Mahâsin at-Ta'wil, Juz 5, (Mesir: "sâ al-Bâbi al-Halabiy, 1959), hlm. 1059.

29 Ahmad Musthafâ al-Marâgiy, Tafsir alMarâgiy, Juz 4, (Beirt: Dâr Ihyâ at-Turâts al'Arabiy, 1985), Cet. ke-2, hlm. 176.

30 Muhammad 'Aliy as-Syâbniy, Syafwah atTafâsir, Juz 1, (Jeddah: Maktabah Jeddah, 1399 H), hlm. 258.

$31 \mathrm{Ab}$ Bakr al-Jazâ'iry, Aysar at-Tafâsir, Jilid 1, (T.t.: Dâr as-Salâm li ath- ${ }^{\circ}$ ibâ' ah wa an-Nasyr wa at-Tawzi', t. t.), hlm. 432.

32 Wahbah az-Zuhayliy, At-Tafsir al-Munir, Juz 4, (Damaskus: Dâr al-Fikr, 1991 M./1411 H.), Cet. ke-1, hlm. 223.

$33 \quad$ Ibid

34 Muhammad Rasyid Ridhâ, Tafsir al-Qur'ân al-Hakim (al-Manâr), Juz 4, (Beirt:Dâr alMa'rifah, t. t.), Cet. ke-2, hlm. 330

35 Ibid.

36 Sayyid Quthb, Fi Zilâl al-Qur'ân, Juz 4, (Beirt: Dâr Ihyâ at-Turâts al-'Arabiy, 1386 HLM./1968 M.), Cet. ke-5, hlm. 236

37 Ibid.

38 Al-'Allâmah as-Sayyid Muhammad Husayn ath-Thabâthabâ'iy, Al-Mizân fi Tafsir alQur'ân, (Iran, Mu'assasah Ismâ'iliyyah, 1412 HLM.), Cet. ke-5, hlm. 136.

39 Menarik untuk dikaji lebih lanjut, mengapa bahasa Arab, bahasa yang digunakan dalam 
al-Qur'an, beberapa benda alam atau namanama benda yang menakjubkan seperti matahari (al-syams), bulan (al-qamar), langit (al-sama'), angin (al-rih), tanah, bumi (al-ardl), jiwa (al-nafs), dan lain sebagainya dikategorikan dalam bentuk (bahasa) perempuan (mu'annats)? Boleh jadi ini berkaitan dengan mitologi Mesir Kuno dan Asia Tengah pada umumnyayang menganut faham The Mother God. Bulan misalnya dianggap sebagai "Ibu Alam Semesta" (The Mother, of Universe) karena mempunyai cahaya yang membawa kesuburan dan sangat penting dalam pertumbuhan dan perkembangan mahluk hidup. Bangsa Arab sebelum datangnya Islam, masih banyak menganggap bulan sebagai dewi yang sangat berpengaruh, dan menurut Owen, dari sinilah sebabnya mengapa umat Islam sejak awal sampai sekarang menjadikan bulan sebagai simbol dan Bulan Sabit menjadi semacam lambang "Palang Merah" dunia Islam. (Lihat Barbra Walker, The Women's Encyclopaedia of Myths and Sacrets, (San Fransisco: Harper \& Row, 1983), hlm. 669. Lihat pula Lara Owen, Her Blood is Gold, Celebrating the Power of Menstruation, (San Francisco: Harper San Francisco, 1993), hlm. 30-31.

Proses peralihan The Mother God ke The Father God membawa implikasi sosial. Beralihnya masyarakat matriarki ke masyarakat patriarki dinilai mempunyai hubungan dengan,peralihan itu. Agama-agama Semit (Yahudi, Kristen, dan Islam) dianggap merombak sistem dan struktur masyarakat matriarki yang pernah dibangun oleh mitologi sebelumnya ke sistem patriarki. (Lihat misalnya Merlin Stone, When God was a Woman, New York, (London: A Havest/HBJ Book Harcourt Brace Jovaniche, 1976), dan J. Edgar Bruns, God as Woman, Woman as God, (New York, Paramus, Toronto: Paulist Press,1973). Akan tetapi Susan Starr Scred tidak setuju membesar-besarkan agama sebagai faktor paling dominan dalam pembentukan suatu sistem masyarakat seperti masyarakat matrifocal atau patrifocal, matriarcal atau patriarcal, dan matrilineal atau patrilineal, karena faktor ekologi dan budaya juga sangat menentukan. Lihat Susan Starr Scred, Priestess, Mother, Sacred Sister Religious Dominated by Women, (New York, Oxford. Oxford University Press, 1984), h, 284.
40 Misalnya dalam Q., s. al-A'rif/7:56 (In-na rahmat-a 'l-Lah-i qarib-un min al-muhsinin), mestinya dikatakan qaribah sebagai sifat dari rahmah yang berbentuk mu'annats, akan tetapi karena shifat men-shifat-i hakekat maushuf yakni al-ihsan yang berbentuk mudzakkar maka shifat pun harus mudzakkar lalu digunakanlah kata qarib.

41 Lihat misalnya Susan Weidman Schneider,Jewish and Female; Choices and Changes in Our Lives Today, (New York: Simon and Schuster,1984), dan Philip Culbertston, The Future of Male Spirituality, (New Adam, Minneapolis: Foetress Press, 1992)

$42 \quad$ Ab al-Fashl Syihâb ad-Din as-Sayyid Mahmd Al-Alsiy al-Bagdâdiy, op. cit., Juz 5, hlm. 34 .

43 Syaykh ath-Thâ'ifah Abi Ja'far Muhammad bin al-Hasan ath-Thusiy, op. cit., hlm. 189.

$44 \quad$ Ibid

45 Imâm Ab al-Qâsim Jârullâh Mahmid bin 'Umar az-Zamahsyariy, op. cit., hlm. 495

46 Muhammad bin Ysuf yang terkenal dengan Ab Hayyâan al-Andalusiy, op. cit., hlm. 239.

47 Al-Hâfidz 'Imâd ad-Din Abu al-Fidâ Ismâ'il bin Katsir al-Qurasyiy ad-Dimasyqiy, op. cit., hlm. 491.

$48 \quad$ Ibid.

49 Al-'Allâmah Jalâl ad-Din Muhammad bin Ahmad al-Mahalliy dan Jalâl ad-Din 'Abd arRahmân bin Abi Bakr as-Suythiy, op. cit., hlm. 77

$50 \quad$ Ab as-Su'd, op. cit., hlm. 517,

51 Muhammad Jamâl ad-Din al-Qâsimiy, op. cit., Jilid 3, hlm. 120.

52 Ahmad Musthafâ al-Marâgiy, op. cit., Juz 5, hlm. 27.

53 Muhammad 'Aliy as-Syâbûniy, op. cit., hlm. 274.

$54 \quad$ Ab Bakr al-Jazâ'iry, op. cit., hlm. 472.

55 Ibid., hlm. 472-473.

56 Wahbah az-Zuhayliy, op. cit., Juz 5, hlm. 53.

$57 \mathrm{Ab}$ al-Husayn Ahmad bin Fâris bin Zakariyyâ, Mu'jam Maqâyis al-Lugah, Juz 5, dinotasi oleh 'Abd as-Salâm Muhammad Hârn, (T. t.: Dâr al-Fikr, t. t.), hlm. 43.

$58 \mathrm{Ab}$ al-Fashl Jamâl ad-Din bin Mukram bin Mandzûr, Lisân al-'Arab, Jilid 12, (Mesir: adDâr al-Mi‘riyyah, t. t.), hlm. 497

$59 \quad$ Ibid., hlm. 503.

60 Al-'Allâmah ar-Râgib al-Ishfahâniy, op. cit., hlm. 690.

61 M. Quraish Shihab, Membumikan Alquran, (Bandung: Mizan, 1992), Cet. ke-2, hlm. 274275. 
62 Lihat Hebrew-English Edition of the Babilonia Talmud, Vol. I (Erubin), (London; Jerusalem: The Sonicino Press, 1976), hlm. $100 \mathrm{~b}$.

63 Lihat Lisa Aiken, To be Jewish Woman, (Northvale, New Jersey, London: Janson Aronson INC., 1992)., hlm. 21

64 Dikutip dari Kitab Bibel edisi Indonesia, hlm. 2.

65 Ibid.

66 Lihat Thomas Buckley and Alma Gottlies (Ed.), Blood Magic, the Antropology of Menstruation, (Berkeley, Los Angeles, London: University ff California Press, 1988), hlm. 6-7. Lihat Pula Paula Weidger, Menstrual and Menopause, The Physiology and Psychology, The Myth and Reality, (New York: Alfred. A. Knoft., 1976), hlm. 85.

67 Judi Grahn, Blood, Bread, and Roses, How Menstruation Created the World, (Bostom: Beacon Press, 1993), hlm. 89-95.

68 Misalnya dalam Q., s. al-Ahzab/33:59 dan s. al-Nur/24:31

69 Diskursus mengenai jilbab dalam agama Yahudi pernah lebih seru dari pada yang belum lama ini diributkan dalam dunia Islam. Dalam Agama Yahudi pernah ditetapkan bahwa membuka jilbab (uncovered) dianggap sebagai suatu pelanggaran yang dapat berakibat jatuhnya talak karena hal tersebut dianggap suatu ketidaksetiaan terhadap suami. ...the woman going out in public pleaces with uncovered constituted legitimate cause for divorce, as through it were synonimous with unfaitfullness. Lihat Louis M. Epstein, Sex Laws and Customs in Judaism, (New York: Ktav Publishing House, INC., 1967), hlm. 36.

\section{$70 \quad$ Ibid}

71 Kata haydl adalah istilah khusus digunakan dalam al-Qur'an istilah ini tidak ditemukan dalam teks Tawrat dan Injil. Dalam AlMunjid fi al-Lughah kata haydl, tanpa menjelaskan asal-usul dan padanannya, dari kata hadla-hadlan yang diartikan dengan keluarnya darah dalam waktu dan jenis tertentu. Lihat Louis Ma'luf, Al-Munjid fi- alLughah, (Beirut: Dar al-Masyriq, 1987), hlm.164. Hanya dalam Lisan al- Arab dikemukakan pendapat lain mengenai asalusul kata tersebut. Menurut Al-Lihyani, Abu Sa'd, dan Abu Sukait, kata hadla dan hasha mempunyai arti yang sama yaitu "mengalir, menampal". Lihat Lisan al-Arab al-Muhith, (Beirut: Dar Lisan al-'Arab, Juz 1, t.t)., hlm.770. Hanya ada kesulitan kalau kedua kata itu diartikan sama, karena keduanya masing-masing mempunyai konteks penggunaan dalam al-Qur'an. Walaupun keduanya hanya disebutkan empat dan lima kali dalam bentuk mashdar dalam al-Qur an tetapi kata mahish lebih banyak berarti "jalan keluar" terhadap berbagai masalah, sedangkan mahidl dipakai dalam konteks darah haid.

72 Q., s. al-Thalaq/65:4 dan s. al-Baqarah/2:222

73 Lihat Tafsir Al-Qur'an al-Azhim, Juz 1, hlm. 258.

74 Banyak lagi riwayat yang serupa disampaikan oleh isteri-isteri Nabi yang lain. Lihat ibid., hlm. 259-260.

75 Kata adzan menurut bahasa berarti sesuatu yang keji dan tidak diinginkan (ma yukrihu min kulli syay'), karena itu kata adzan dalam tafsir yang berbahasa Indonesia sering diartikan dengan penyakit dan juga sering pula dengan kotoran. Bahkan menurut Thabathaba'i darah haid itu sendiri bukan dzat ('ayn)-nya yang darurat melainkan sesuatu yang dari luar (dlarurah lighayrih) kemudian memberi nilai tersendiri, seperti firman Allah dalam s. al-Ahzab/33:57: "Sesungguhnya orang-orang yang menyakiti Allah dan Rasul-Nya." Maksudnya bukan menyakiti Allah dan Rasul-Nya secara fisik melainkan melakukan perbuatan-perbuatan yang tidak diridlai oleh Allah dan RasulNya. Demikian pula dalam ayat haydl tadi, bukan haydl-nya ansich yang adzan tetapi karena kedatangan darah haid itu setiap bulan dan membawa masalah bagi perempuan. Lihat Thabathaba'i; Tafsir alMizan, Juz 2, hlm. 207

$76 \quad$ Al-Razi, Tafsir al-Kabir, Juz hlm. 64.

77 Kata thaharah termasuk kata yang sering muncul dalam kitab suci terdahulu, seperti dalam kitab Taurat sering dihubungkan dengan mikvah/family purity yaitu melakukan mandi secara ritual dengan air yang telah diberkahi, biasanya pada petang hari ketujuh masa menstruasi. Lihat Lisa Aiken, op. cit, hlm. 164-165. Makna thaharah tersebut mempunyai kemiripan fungsi dalam Islam, yaitu melakukan pembersihan sesudah melakukan persetubuhan atau seusai menjalani menstnrasi. Hanya dalam Tafsir al-Alusi memberikan komentar bahwa yang dimaksud bersih dari ayat tersebut ialah pembersihan secara hakiki, yakni melakukan pembersihan diri secara 
sempurna (al-thaharah al-kamilah) dengan mandi, maksudnya berhentinya haid tidak bisa dijadikan ukuran tetapi mandi wajib sesudah haid itulah yang dijadikan 'ibarahlm. Al-Alusi cenderung sependapat dengan 'Ashim yang membaca yaththahharna (dengan tasdiq) yang memfaedahkan upaya intensif untuk membersihkan diri. Lihat Tafsir al-Alusi, Juz 2.: hlm.123. Imam Syafi'i cukup dengan mandi seperti mandi janabah, yakni membasahi seluruh anggota badan, sebagian ulama lain seperti 'Atha' dan Thawus berpendapat bahwa perempuan pasca haid mesti mandi dan berwudlu. Lihat al-Razi dalam op. cit" hlm. 69.

78 Angka tujuh di sini semata-mata berdasar pada kebiasaan perempuan bahwa umumnya mereka menjalani masa haid selama tujuh hari, tidak ada hubungannya sama sekali dengan angka tujuh seperti yang dianut dalam agama Yahudi. Ini bisa dilihat dalam diskursus empat imam madzhab: Imam Abu Hanifah, Imam Malik, Imam Syafi'i, dan Imam Ahmad, sama sekali tidak pernah ada yang menyinggung hubungan antara angka tujuh hari dengan penciptaan dan perilaku makrokosmos.

79 Lihat Tafsir al-Qur'an al-'Azhim, Juz 1, ...hlm.258.

\section{DAFTAR PUSTAKA}

$\mathrm{Ab}$ al-Fashl Jamâl ad-Din bin Mukram bin Mandzûr, Lisân al-'Arab, Jilid 12, (Mesir: ad-Dâr al-Mi‘riyyah, t. t.)

Ab al-Fashl Syihâb ad-Din as-Sayyid Mahmd Al-Alsiy al-Bagdâdiy, op. cit., Juz 5

Ab al-Husayn Ahmad bin Fâris bin Zakariyyâ, Mu'jam Maqâyis al-Lugah, Juz 5, dinotasi oleh 'Abd as-Salâm Muhammad Hârn, (T. t.: Dâr al-Fikr, t. t.)

$\mathrm{Ab}$ as-Su'd, Tafsir Abi as-Su'd (Irsyâd al-'Aql as-Salim ilâ Mazâyâ al-Kitâb al-Karim), Juz 1, (T.T.: Dâr al-Fikr, t. t.)

Ab Bakr al-Jazâ'iry, Aysar at-Tafâsir, Jilid 1, (T.t.: Dâr as-Salâm li ath- ${ }^{\circ}$ ibâ'ah wa an-Nasyr wa at-Tawzi', t. t.)
Ahmad Musthafâ al-Marâgiy, Tafsir alMarâgiy, Juz 4, (Beirt: Dâr Ihyâ atTurâts al-'Arabiy, 1985), Cet. ke-2

Al-'Allâmah as-Sayyid Muhammad Husayn ath-Thabâthabâ'iy, Al-Mizân fi Tafsir al-Qur'ân, (Iran, Mu'assasah Ismâ' iliyyah, 1412 HLM.), Cet. ke-5

Al-'Allâmah Jalâl ad-Din Muhammad bin Ahmad al-Mahalliy dan Jalâl ad-Din 'Abd ar-Rahmân bin Abi Bakr as-Suythiy, Tafsir al-Qur'ân al-Karim (Tafsir Jalâlayn), Juz 1, (Surabaya: alMaktabah as-Saqâfiyyah, 1345 H.)

Al-Hâfidz 'Imâd ad-Din Ab al-Fidâ Ismâ'il bin Katsir al-Qusyayriy adDimasyqiy, Tafsi al-Qur'ân al-'Adzim, Juz 1, (Semarang: Toha Putra, t. t.)

ath-tusiy, At-Tibyân fi Tafsir al-Qur'ân, Jilid 3, dinotasi oleh Ahmad Hâsib Qa،ir al'Àmiliy, (T. t.: Maktabah al-'Àlam alIslâmiy, t. t.)

Barbra Walker, The Women's Encyclopaedia of Myths and Sacrets, (San Fransisco: Harper \& Row, 1983)

C.T. Onionss (ed.), The Word Dictionary of English Etymology, (Oxford: Oxford at the Clarendon Press, 1979)

Elaine Showalter (Ed.), Speaking of Gender, (New York \& London: Routledge, 1989)

Frederick Engels, The Origin of Family Private Property and State, (New York: International Publisher Company, 1976).

Hebrew-English Edition of the Babilonia Talmud, Vol. I (Erubin), (London; Jerusalem: The Sonicino Press, 1976)

Hilary M. Lips, Sex E Gender an Introduction, (California, London, Toronto: Mayfield Publishing Company, 1993) 
Hilary M. Lips, Sex and Gender: An Introduction (California: Mayfield Publishing Company, 2001)

HLM.T. Wilson, Sex and Gender, Making Cultural Sense of Civilization, (Leiden, New York, Kobenhavn, Koln: EJ. Brill, 1989)

http://www.paramadina.com

Imâm $\mathrm{Ab}$ al-Qâsim Jârullâh Mahmd bin 'Umar az-Zamahsyariy, Al-Kasysyâf 'an Haqấ'iq Gawâmi at-Tanzil wa 'Uyn al-Aqâwwil fi Wujh at-Ta'wil, Juz 1, (Beirt: Dâr al-Kutub al-'Ilmiyyah, 1415 H./1995 M.)

John M. Echols dan Hasan Shadily, Kamus Inggris Indonesia (Jakarta: Gramedia cetakan XXIII, 1996)

John M.Echols dan Hassan Shadily, Kamus Inggeris Indonesia, (Jakarta: Gramedia, cet. XII, 1983)

Judi Grahn, Blood, Bread, and Roses, How Menstruation Created the World, (Bostom: Beacon Press, 1993)

Kantor Menteri Negara Urusan Peranan Perempuan, Buku III: Pengantar Teknik Analisa Jender, 1992

Kitab Bibel edisi Indonesia

Lara Owen, Her Blood is Gold, Celebrating the Power of Menstruation, (San Francisco: Harper San Francisco, 1993)

Leila Ahmed adalah Women and Gender in Islam: Historical Roots of a Modern Debate" (Perempuan dan Gender dalam Islam: Akar-akar Historis Perdebatan Modern).

Linda L. Lindsey, Gender Roles a Sociological Perspective, (New Jersey: Prentice Hall, 1990)
Lisa Aiken, To be Jewish Woman, (Northvale, New Jersey, London: Janson Aronson INC., 1992).

Lisan al-Arab al-Muhith, (Beirut: Dar Lisan al'Arab, Juz 1, t.t)

Louis M. Epstein, Sex Laws and Customs in Judaism, (New York: Ktav Publishing House, INC., 1967)

Louis Ma'luf, Al-Munjid fi-al-Lughah, (Beirut: Dar al-Masyriq, 1987)

M. Quraish Shihab, Membumikan Alquran, (Bandung: Mizan, 1992), Cet. ke-2

Mansour Fakih, Analisis Gender dan Transformasi Sosial, (Yogyakarta: Pustaka Pelajar,1996)

Merlin Stone, When God was a Woman, New York, (London: A Havest/HBJ Book Harcourt Brace Jovaniche, 1976), dan J. Edgar Bruns, God as Woman, Woman as God, (New York, Paramus, Toronto: Paulist Press,1973).

Muhammad 'Aliy as-Syâbniy, Syafwah atTafâsir, Juz 1, (Jeddah: Maktabah Jeddah, 1399 H)

Muhammad bin Yusuf yang terkenal dengan Abu Hayyân al-Andalusiy, Tafsir alBahr al-Muhith, Jilid 3, (Beirt: Dâr alFikr, 1983 M./1403 H.), Cet. ke-2

Muhammad Jamâl ad-Din al-Qâsimiy, Mahâsin at-Ta'wil, Juz 5, (Mesir: "sâ alBâbi al-Halabiy, 1959)

Muhammad Rasyid Ridhâ, Tafsir al-Qur'ân alHakim (al-Manâr), Juz 4, (Beirt:Dâr alMa'rifah, t. t.), Cet. ke-2

Nasaruddin Umar, Argumen Kesetaraan Jender (Jakarta: Paramadina, 2001)

Paula Weidger, Menstrual and Menopause, The Physiology and Psychology, The Myth 
and Reality, (New York: Alfred. A. Knoft., 1976)

Philip Culbertston, The Future of Male Spirituality, (New Adam, Minneapolis: Foetress Press, 1992)

Riffat Hasan, "Teologi Perempuan dalam Tradisi Islam," dalam Ulumul Qur'an, Vol.1, 1990/1410

Riffat Hasan, "Teologi Perempuan dalam Tradisi Islam", dalam Jurnal Ulumul Qur'an No. 4, Vol. I., tahun 1990

Sayyid Quthb, Fi Zilâl al-Qur'ân, Juz 4, (Beirt: Dâr Ihyâ at-Turâts al-'Arabiy, 1386 HLM./1968 M.), Cet. ke-5

Susan Starr Scred, Priestess, Mother, Sacred Sister Religious Dominated by Women, (NewYork, Oxford. Oxford University Press, 1984)

Susan Weidman Schneider,Jewish and Female; Choices and Changes in Our Lives Today, (New York: Simon and Schuster,1984)

Syaykh ath-Thâ'ifah Abi Ja'far Muhammad bin al-Hasan ath-Thusiy, op. cit., hlm. 189.

Thomas Buckley and Alma Gottlies (Ed.), Blood Magic, the Antropology of Menstruation, (Berkeley, Los Angeles, London: University ff California Press, 1988)

Wahbah az-Zuhayliy, At-Tafsir al-Munir, Juz 4, (Damaskus: Dâr al-Fikr, 1991 M./1411 H.), Cet. ke-1

Victoria Neufeldt (ed.), Webster's New World Dictionary, (New York: Webster's New World Cleveland, 1984) 